After a meeting last Friday, June 7, between Mr D. J. Maclean, Deputy Secretary (Scientific) of the NERC, and the admiral in charge of the Devonport Dockyard, the NERC has concluded that the dockyard will be unsuitable. The Navy would not be able to offer the unit civilian facilities at a naval dockyard. While berth space could be arranged, the Navy could not guarantee permanent berths and could not give land for equipment storage next to the vessels. Without these conditions, the NERC does not consider the Devonport Docks to be a viable solution and is now planning to look for a new site on the Severn if it is unable to change the decision of the Ministry of Transport to close the Barry docks.

\section{Poisoned Mussels}

Investigations are continuing into the cause of the poisoned mussels and of the death of hundreds of sea birds along the north-east coast of Britain. Everything points to a dinoflagellate "bloom" as the agent responsible, but so far it is proving difficult to track down and identify the specific organism producing the toxicity. It may possibly be a species of the dinoflagellate Gonyaulax but, so far, shore-line plankton samples along the Tyneside coast down as far as Hartlepool have proved negative. Samples are now being taken 4 miles off-shore and research vessels from the Ministry of Agriculture's Fisheries Laboratory at Lowestoft, and from the University of Newcastle, are helping in the operation. It is definitely all hands to the pumpsthere are now ten different groups of people concerned, and the main centres of activity are in Newcastle at the public health laboratory and at the university where Professor R. B. Clark of the Department of Zoology is leading operations. Work is also being done on the problem at the university's Dove Marine Laboratory at Cullercoats and at the University of Leeds Wellcome Marine Laboratory at Robin Hood's Bay. The birds are being investigated by Dr John Coulson of the Zoology Department, University of Durham.

Dinoflagellates are planktonic protozoa abundant in both marine and fresh waters. Sometimes they occur as blooms, becoming very abundant for a short time and then practically disappearing. Most species are harmless and form an important source of food for other organisms. A few species are, however, toxic and it is one of these that is suspected. Marine blooms of one reddish form produce "red tides" which occur along the Atlantic coast of the southern United States and kill fish in large numbers. These toxic "blooms" are not, however, confined to tropical and sub-tropical waters. They are found occasionally in the cold waters of the Bay of Fundy and in fjords in Norway, but are almost unknown in British waters. It is thought that the toxicity recorded in the north-east was causcd by the normal spring bloom of a dinoflagellate "overbursting itself" as a result of a combination of a particular climatic condition and the right nutrients. It seems that the centre of the population explosion was around the Farne Islands. Indeed, one of the highest levels of natural toxicity ever recorded in the world was found on Holy Island.

The story first made news at the end of May, when some seventy cases of human enteritis were linked to poisoned mussels. None of the cases was very serious and the outbreak of poisoning was over quite quickly, as shellfish supplies were stopped and people were warned against eating any shellfish from the Northumberland coast. Since then, hundreds of shags (small cormorants) and other sea birds have been found dead on the Farne Islands and elsewhere on the Northumberland and Durham coast, and dead sand eels and flounders were washed up. The toxicity does not appear to be confined to the Farne Island district. There have been reports of it as far north as the Firth of Forth and south down to Bridlington. Officials from the Ministry of Agriculture and from the Department of Agriculture and Fisheries for Scotland are keeping a look-out all the way along the coast in case the toxicity is spreading further, and work is continuing to identify all the links in the food chains of the animals concerned.

\section{Australia Goes Metric?}

The United States and Canada may soon be the only two major countries still using the imperial system of weights and measures, if Australia follows the recommendations of a recent Senate committee report (Report from the Senate Select Committee on the Metric System of Weights and Measures, Parliament of the Commonwealth of Australia, 1968). The committee recommends that the use of imperial units be discontinued over a period of ten years and be replaced by the metric system, known as the International System of Units.

A major factor influencing the committee's decision was Australia's position in world trade: more than 90 per cent of the world's population is now living under a metric system and 75 per cent of the world's machine tools are produced in metric countries. Britain's decision to convert to the metric system by 1975 also influenced the committee. British industrial standards-on which Australia has always drawn heavily-will in future be metric, the future distribution of Australia's trade will be much more heavily loaded in favour of metric countries, and Britain's experiences in breaking new ground will be most helpful to Australia.

As evidence of the ease of conversion, the committee pointed to the fairly recent experiences of India and Japan. India, with relatively light industrialization, had little trouble teaching the new system even to illiterate villagers. Against this rural experience, Japan, highly industrialized and with a large international trade, began a positive programme of conversion in 1955 which was 85 per cent complete four years later. Evidence is that industry and commerce are pleased with the change, and major industries have claimed substantial savings in production costs following conversion.

If Australia does decide to convert, the United States will remain the outstanding country on the imperial system, but she is in many ways a unique case. While there have been many moves in Congress to initiate a study of the practicality of the metric system, none of these has yet been implemented. Many industries and technical publications already use the metric system, either exclusively or on a dual basis, but since more than 90 per cent of America's products are consumed internally, there is little outside pressure for total conversion. Also, the United States is already so heavily industrialized that the 